\title{
Studies in Semitic Vocalisation and Reading Traditions
}

\section{Edtted by Aaron D. Hornkohl and Geoffrey Khan}

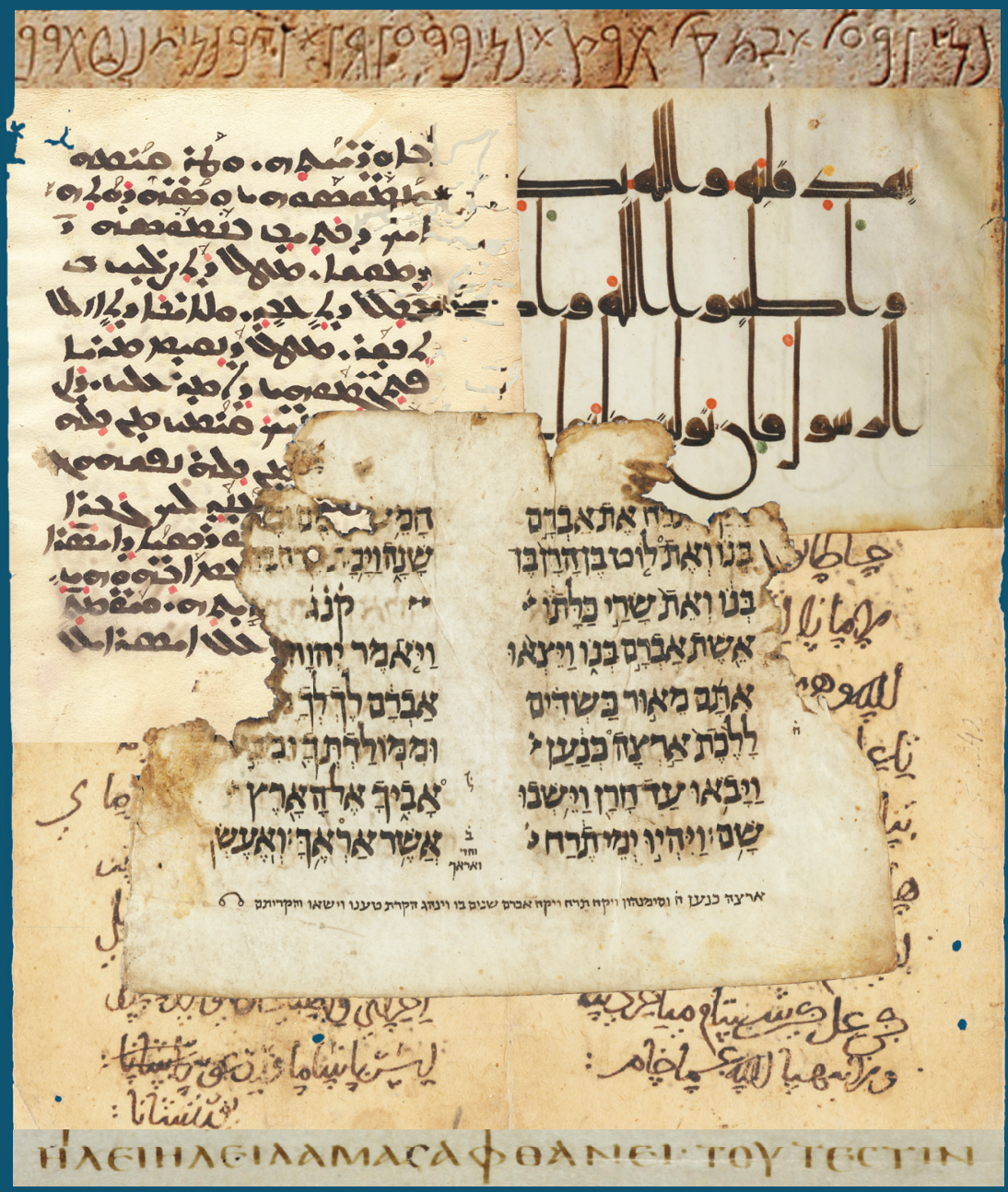




\section{https://www.openbookpublishers.com}

(C) 2020 Aaron D. Hornkohl and Geoffrey Khan. Copyright of individual chapters is maintained by the chapters' authors.

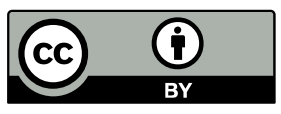

This work is licensed under a Creative Commons Attribution 4.0 International license (CC BY 4.0). This license allows you to share, copy, distribute and transmit the text; to adapt the text and to make commercial use of the text providing attribution is made to the authors (but not in any way that suggests that they endorse you or your use of the work). Attribution should include the following information:

Aaron D. Hornkohl and Geoffrey Khan (eds.), Studies in Semitic Vocalisation and Reading Traditions. Cambridge, UK: Open Book Publishers, 2020, https://doi.org/10.11647/OBP.0207

In order to access detailed and updated information on the license, please visit, https:// doi.org/10.11647/OBP.0207\#copyright

Further details about CC BY licenses are available at, https://creativecommons.org/ licenses/by/4.0/

All external links were active at the time of publication unless otherwise stated and have been archived via the Internet Archive Wayback Machine at https://archive.org/web

Updated digital material and resources associated with this volume are available at https://doi.org/10.11647/OBP.0207\#resources

Every effort has been made to identify and contact copyright holders and any omission or error will be corrected if notification is made to the publisher.

Semitic Languages and Cultures 3.

ISSN (print): 2632-6906

ISSN (digital): 2632-6914
ISBN Paperback: 978-1-78374-935-5

ISBN Hardback: 978-1-78374-936-2

ISBN Digital (PDF): 978-1-78374-937-9

DOI: $10.11647 / \mathrm{OBP} .0207$

Cover image: Detail from a bilingual Latin-Punic inscription at the theatre at Lepcis Magna, IRT 321 (accessed from https://it.wikipedia.org/wiki/File:Inscription_Theatre_ Leptis_Magna_Libya.JPG). Leaf of a Syriac prayer book with Western vocalisation signs (source: Wikimedia Commons). Leaf of an Abbasid-era Qurān (vv. 64.11-12) with red, yellow, and green vocalisation dots (source: Wikimedia Commons). Genizah fragment of the Hebrew Bible (Gen. 11-12, Cambridge University Library T-S A1.56; courtesy of the Syndics of Cambridge University Library). Genizah fragment of a Karaite transcription of the Hebrew Bible in Arabic script (Num. 14.22-24, 40-42, Cambridge University Library T-S Ar. 52.242; courtesy of the Syndics of Cambridge University Library). Greek transcription of the Hebrew for Ps. 22.2a in Matt. 27.46 as found in Codex Bezae (fol. 99v; courtesy of the Syndics of Cambridge University Library).

Cover design: Anna Gatti 


\section{VOWEL QUANTITY AND QUALITY IN NEO-PUNIC AND LATIN INSCRIPTIONS FROM AFRICA AND SARDINIA ${ }^{1}$}

\section{Robert Crellin and Lucia Tamponi}

\subsection{INTRODUCTION}

We survey two sources of inscriptional evidence-Neo-Punic inscriptions from North Africa and Latin and Neo-Punic inscriptions from Sardinia-exploring the implications for better understanding the structure of the Neo-Punic vowel system, that of Latin in

\footnotetext{
${ }^{1}$ The paper was jointly conceived by the two authors. The composition was divided up as follows: $\S \S 1,2.4$, and 3.7 were jointly authored; the author of $\S \S 2.1-3$ and 3.6 was Robert Crellin; $\S \S 3.1-3.5$ were authored by Lucia Tamponi. We would like to thank Prof. Giovanna Marotta and Francesco Rovai for their support and thought-provoking comments, as well as the editors for their careful reading and helpful suggestions. Needless to say, any remaining shortfalls remain the responsibility of the authors. We would also like to thank Karel Jongeling for providing us with a copy of his $\mathrm{PhD}$ dissertation. Robert Crellin completed his contribution as part of ongoing research under the CREWS (Contexts of and Relations between Early Writing Systems) project, the European Research Council (ERC) under the Horizon 2020 research and innovation programme (grant agreement No. 677758).
} 
North Africa, and what relationship these might have to the development of the Latin vowel system in Sardinia. On the basis of the evidence given, we suggest that the non-participation of Sardinian Latin and Sardinian Romance in the merger of $/ \mathrm{i}$, e:/ and $/ \mathrm{u}, \mathrm{o} / \mathrm{in}$ Common Romance is to be linked to the strong distinction of these phonemes in North African Latin. Furthermore, we provide evidence for the early collapse of vowel quantity distinctions in North African Latin, so that the same development in Sardinian Romance may plausibly be seen as part of the same phenomenon, a result of contact with North Africa.

In order to show this, we devote the first section to giving a detailed survey of the representation and non-representation of vowels in a set of Roman personal names occurring in Neo-Punic inscriptions from North Africa, in terms of both vowel quality and quantity. In the second section these results are compared with a survey of the vowel alternations $\langle\mathrm{e}\rangle /<\mathrm{i}\rangle$ and $\langle\mathrm{o}\rangle /\langle\mathrm{v}\rangle$ in a set of Latin inscriptions from Sardinia. Finally, supporting evidence is adduced from Neo-Punic inscriptions in Sardinia.

\subsection{NEO-PUNIC IN NORTH AFRICA}

\subsection{Introduction}

\subsubsection{Corpus and Dating}

The Late Punic corpus consists almost entirely of lapidary inscriptions (Jongeling and Kerr 2005, 1); it is unfortunate that no documentary material written on perishable material has survived. The basis for the present investigation is the set of Latin personal 
names from inscriptions from North Africa (modern Algeria, Tunisia, and Libya) given in the 'Onomasticon' section of the NeoPunic corpus of Jongeling (2008).

For purposes of the present investigation, the following vowel tokens were excluded:

- Vowel tokens where there is doubt as to the correct reading of the token, as indicated in Jongeling (2008); ${ }^{2}$

- Tokens from names where the quantities could not be found either in Lewis and Short (1879), Gaffiot (1934), or Forcellini et al. (1940); ${ }^{3}$

- Tokens marked reconstructed or uncertain in Jongeling (2008);

${ }^{2}$ In addition, names whose Roman identification is indicated by Jongeling as uncertain are on the whole excluded. This includes: $b^{5} t^{2}, k l n y$,

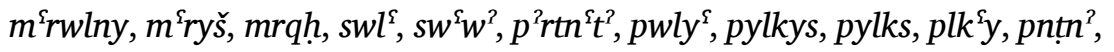
$q^{\uparrow} p t^{2}, q^{\uparrow} \check{s} y^{2}, q r n t^{2}, r^{2} s t t y t^{2}, r y d^{\uparrow} y$. In addition, $y^{\uparrow} n w^{\uparrow} r$ for Januaria is excluded on the grounds of being a shortened form. Greek names which occur in a parallel Latin transcription are included. The name wyt $t^{\lceil} l^{2}$ is given as Vitalus by Jongeling. However, this name does not occur in Forcellini et al. (1940), whereas the name Vitalis does occur. Accordingly, the quantities for Vitalus are taken from Vitalis.

${ }^{3}$ Access to Gaffiot (1934) and Forcellini et al. (1940) was provided by Brepolis (http://apps.brepolis.net/BrepolisPortal/default.aspx). Access to Lewis and Short was also provided by Diogenes v. 3.2.0 (http://community.dur.ac.uk/p.j.heslin/Software/Diogenes/index.php), in which the text of Lewis and Short is, in turn, provided by the Perseus Project (http://www.perseus.tufts.edu/hopper/). 
- $\quad\left\langle^{\prime}>\right.$ tokens corresponding to the final syllable of Latin second declension masculine termination -us, e.g., Severus. These likely represent /e/ (cf. Jongeling 1984, 96; 2003, 119; Kerr 2010, 44, 68-74). These were excluded on the grounds that the sheer quantity of such forms would skew the results;

- $\quad\langle y>$ tokens corresponding to the Latin second declension masculine termination -ius and -eus, e.g., Aelius (cf. Jongeling 1984, 96; Kerr 2010, 68-74). These were excluded for the same reason as those terminating in -us.

Any additional restrictions imposed for a particular part of the investigation are noted in relation to that part.

The modern country of origin of the vowel tokens considered for the present investigation is given in Table 1. Tokens from inscriptions in Italy and Sardinia are excluded in order to be in a position to assess the relationship between the Sardinian and North African systems on the basis of the Sardinian Latin inscriptions in $\S 3$.

Table 1: Locations of vowel token instances

\begin{tabular}{|l|c|c|}
\hline Country & Vowel token count & Inscriptions \\
\hline Algeria & 20 & 10 \\
\hline Libya & 155 & 25 \\
\hline Tunisia & 222 & 67 \\
\hline Sum & 397 & 102 \\
\hline
\end{tabular}

It should be observed at the outset that terms in the study of the Punic language and its epigraphy are used differently by different scholars. Following Jongeling and Kerr (2005, 1), we use the term 'Punic' to refer to both the variety of the Phoenician 
language spoken and used under the Carthaginians and the Punic language written in Phoenician script. By contrast, we use the term 'Neo-Punic' to refer to the Punic language as written in the Neo-Punic script, which is conventionally dated to post-146 BCE, i.e., after Carthage's final defeat at the hands of Rome. We say 'conventionally', since it should also be borne in mind that dating these changes with any degree of precision is problematic owing to the nature of the evidence, as Wilson (2012, 265-66) observes: "Most neo-Punic inscriptions are undatable on internal evidence, and are dated after $146 \mathrm{BC}$ on the basis of the cursive script-and this dating is then used, by a circular argument, to date the script [...]". The Neo-Punic corpus as a whole can, however, be dated between the first century BCE and the second century CE (Ferjaoui 2007, 34).

The investigation does not concern Latino-Punic or GrecoPunic texts, that is, Late Punic texts written in the Latin and Greek alphabets, respectively. For a detailed study of this corpus, see Kerr (2010).

\subsubsection{Previous Research: Vowel Writing in Neo-Punic}

Phoenician and Punic, prior to the Third Punic War, had been very conservative in respect of the representation of vowel phonemes, so that in most cases vowels are not recorded. However, in Neo-Punic the use of matres lectionis becomes much more prevalent.

Considerable work has been done over the last couple of decades to show that the representation of vowels in Neo-Punic is not haphazard (Jongeling 2003; Kerr 2010, 38). Even so, the 
system cannot be said to have been unified or standardised (cf. Friedrich and Röllig 1999, §107).

The basic correspondences may be given as in Table 2 .

Table 2: Matres lectionis in Neo-Punic orthography (adapted from Jongeling and Kerr 2005, 7)

\begin{tabular}{|c|c|c|}
\hline Mater & Name & Vowel phoneme represented \\
\hline$<^{\prime}>$ & 'alef & $/ \mathrm{o} /, / \mathrm{e} /, / \mathrm{u} /$ \\
\hline$<\mathrm{h}>$ & he & $/ \mathrm{a} /$ \\
\hline$<\mathrm{w}>$ & waw & $/ \mathrm{u} /$ \\
\hline$<\mathrm{h}>$ & heth & $/ \mathrm{a} /$ \\
\hline$<\mathrm{y}>$ & yodh & $/ \mathrm{i} /$ \\
\hline$<^{\mathrm{c}}>$ & 'ayin & $/ \mathrm{a} /$ \\
\hline
\end{tabular}

The following points are worth noting:

1. /a/ is represented by no fewer than three different matres: $\left.\left.<^{\mathrm{c}}\right\rangle,<\mathrm{h}\right\rangle$, and $<\mathrm{h}>$. Despite this, $\left.<^{\mathrm{c}}\right\rangle$ is the usual way of representing this vowel (Jongeling and Kerr 2005, 8);

2. $<>>$ represents $/ \mathrm{o} /, / \mathrm{e} /$, and $/ \mathrm{u} /$-surprising since one, $/ \mathrm{e} /$, is on the front axis, while the other two are on the back axis;

3. $<^{\mathrm{c}}>$ and $<\mathrm{h}>$ are used as matres, something unknown in Hebrew and Aramaic varieties, with the exception of Mandaic, where 'ayin is used as a mater lectionis (see Nöldeke 1875, 5-6).

Jongeling (1984) looked specifically at the transcription of Roman names into Neo-Punic. From his investigation, it is again striking that several graphemes, namely $\left.<^{\prime}\right\rangle,\langle\mathrm{h}\rangle,\langle\mathrm{w}\rangle$, and 
$\langle\mathrm{y}\rangle$, have multiple interpretations. However, Jongeling does not provide figures for correspondences between vowel phonemes and their graphemes. Furthermore, he is primarily concerned with the manner of active denotation of vowels, and does not address the question of zero representation. It is these points which the present study seeks to address, and in so doing to provide additional clarity in regard to the principal distribution of vowel graphemes in Neo-Punic.

It is interesting to note in passing that $<\mathrm{h}>$ is not attested in names of Latin origin (Jongeling 1984, 104).

\subsubsection{Method: From Graphemes to Phonemes}

The transcription of Roman names into Neo-Punic can help us understand the structure of the Late Punic vowel system, since we know, at least in principle, what the structures are that are supposed to be represented. In what follows we set out to establish what may be deduced in respect of:

1. The representation of vowels in the Neo-Punic writing system, in terms of whether or not a particular vowel phoneme is represented;

2. When a particular vowel phoneme is represented, the means by which it is represented;

3. The shape of the Latin vowel system in North Africa at the time of the Neo-Punic inscriptions.

However, it should be observed that we are matching Punic vowel graphemes to Latin vowel graphemes, not phonemes to phonemes or graphemes to phonemes (for this point see also Jongeling 1984, 95-96). Indeed, we could in principle be dealing 
with transliteration into Neo-Punic, rather than transcription. If this were the case, the correspondences would merely tell us how users of the Neo-Punic writing system thought the graphemes should correspond.

We need first, then, to establish that we are dealing with a transcription, rather than transliteration system. This is easily seen from an analysis of the rendering of Latin graphemes into Neo-Punic. For if we were dealing with a system of transliteration, we would expect to find two things:

1. Every Latin vowel grapheme being represented in NeoPunic;

2. Consistency in the representation of vowel graphemes.

An analysis of Table 3 andTable 4 below shows that, while there may be trends in the rendering of Latin vowel graphemes, they can hardly be said to be particularly consistent in terms of either the fact or the manner of representation. We therefore take it to be the case that we are dealing with a transcription system, that is, an attempt on the part of inscribers using Neo-Punic script to render the Latin sounds they perceived according to Neo-Punic spelling rules or tendencies. This is important, since it allows us to move from Neo-Punic graphemes to Latin phonemes.

\subsection{Vowel Representation in Neo-Punic: Analysis by Quality and Quantity}

\subsubsection{Vowel Quality}

Previous studies of vowel representation in Neo-Punic have focused on the manner in which vowel phonemes are actively represented (cf. the previous section). If we look at this question, the 
data provided in the present investigation more or less conform to the picture given in $\S 2.1 .2$ above, whereby $/ \mathrm{a} /$ is primarily represented by $\left.<^{\mathrm{c}}\right\rangle$, /e/ and /o/ by $\left.<^{\mathrm{\prime}}\right\rangle$, /u/ by $\langle\mathrm{w}\rangle$, and $/ \mathrm{i} /$ by $\langle\mathrm{y}\rangle$. Consider the figures given in Table $3 .{ }^{4}$ For the time being, diphthongs are excluded from consideration. These will be examined separately at $\S 2.4 .3$ below.

Table 3: Latin vowel quality representation in Neo-Punic (observed token frequencies, percentages in parentheses)

\begin{tabular}{|c|c|c|c|c|c|c|c|}
\hline & $<>$ & $\left.<^{\prime}\right\rangle$ & $<\mathrm{h}>$ & $<\mathrm{w}>$ & $<y>$ & $\begin{array}{l}\underset{\tilde{0}}{0} \\
\qquad\end{array}$ & 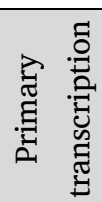 \\
\hline /a/ & $113(95)$ & $5(4)$ & $1(1)$ & - & - & 119 & $<>$ \\
\hline$/ \mathrm{e} /$ & - & $12(80)$ & $3(20)$ & - & - & 15 & $\left.<^{\prime}\right\rangle$ \\
\hline$/ \mathrm{i} /$ & - & - & - & - & $48(100)$ & 48 & $<y>$ \\
\hline $10 /$ & - & $10(91)$ & $1(9)$ & - & - & 11 & $<>$ \\
\hline$/ \mathrm{u} /$ & - & $9(41)$ & $1(5)$ & $11(50)$ & $1(5)$ & 22 & $<\mathrm{w}>$ \\
\hline
\end{tabular}

However, this ignores the fact that many vowel phoneme tokens are not represented in Neo-Punic. If we take these 'zero' representations into account, the picture looks somewhat different, as may be seen in Table 4.

\footnotetext{
${ }^{4}$ Percentage totals throughout may not add up to exactly 100 owing to rounding to the nearest integer.
} 
Table 4: Latin vowel quality representation in Neo-Punic including zero marking (observed token frequencies, percentages in parentheses)

\begin{tabular}{|c|c|c|c|c|c|c|c|c|}
\hline & $<\emptyset>$ & $<^{c}>$ & $\left.<^{\prime}\right\rangle$ & $<\mathrm{h}>$ & $<w>$ & $<y>$ & స్ & 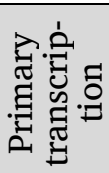 \\
\hline$/ \mathrm{a} /$ & $\begin{array}{c}8 \\
(6)\end{array}$ & $\begin{array}{l}113 \\
(89)\end{array}$ & $\begin{array}{c}5 \\
(4)\end{array}$ & $\begin{array}{c}1 \\
(1)\end{array}$ & - & - & 127 & $\langle c\rangle$ \\
\hline /e/ & $\begin{array}{c}41 \\
(73)\end{array}$ & & $\begin{array}{c}12 \\
(22)\end{array}$ & $\begin{array}{c}3 \\
(5)\end{array}$ & - & - & 56 & $<\emptyset>$ \\
\hline /i/ & $\begin{array}{c}27 \\
(36)\end{array}$ & - & - & - & - & $\begin{array}{c}48 \\
(64)\end{array}$ & 75 & $<\mathrm{y}>$ \\
\hline /o/ & $\begin{array}{c}22 \\
(67)\end{array}$ & - & $\begin{array}{c}10 \\
(30)\end{array}$ & $\begin{array}{c}1 \\
(3)\end{array}$ & - & - & 33 & $<\emptyset>$ \\
\hline$/ \mathrm{u} /$ & $\begin{array}{c}65 \\
(75)\end{array}$ & & $\begin{array}{c}9 \\
(10)\end{array}$ & $\begin{array}{c}1 \\
(1)\end{array}$ & $\begin{array}{c}11 \\
(13)\end{array}$ & $\begin{array}{c}1 \\
(1)\end{array}$ & 87 & $<\emptyset>$ \\
\hline
\end{tabular}

It may be seen from the table that in the case of three vowel qualities-/e/, /o/, and $/ \mathrm{u} /$-zero is the primary transcription, and only in the case of $/ a /$ and $/ \mathrm{i} /$ is active transcription preferred. In addition, it is worth noting that $\langle$ ' $\rangle$ is the primary means of rendering no phoneme in particular. This is to say that $\langle>>$ indicates the presence of a vowel, without specifying its quality (for the polyvalence of $<$ '>, see also Jongeling 2003, 121).

In order to gain clarity on the rationale for the distribution, it is also important to assess the manner in which vowel quantity is represented. 


\subsubsection{Vowel Quality and Quantity}

Jongeling $(1984,109)$, in a section on the transcription of Roman names into Neo-Punic, observes that the length of consonants and vowels is not expressed in Neo-Punic. Our data show, on the one hand, that strictly speaking this is true, in that a vowel of a given quality may be represented in the same way regardless of its length. On the other hand, however, long and short vowels are not equally likely to be represented.

Table 5 gives the means by which the vowels in Roman names are transcribed, with the vowel quantities as they would be expected to be in Classical Latin. These quantities were obtained by checking each Latin name in the Neo-Punic corpus against the quantities listed in Lewis and Short (1879), Gaffiot (1934), and/or Forcellini et al. (1940). For the analysis of vowel quality and quantity, in addition to the exclusions listed in $\$ 2.1 .1$ above, the following tokens were excluded:

- Initial and final vowels, since these are almost obligatorily represented regardless of quantity (or quality);

- Tokens occurring in closed syllables, that is, syllables of the shape (C)VCC were also excluded, since it is difficult to be sure of the length of the vowel in these cases;

- Tokens occurring in words terminating in -ius or -eus. These were excluded for comparability in later sections, where the Latin stress is taken into consideration (see especially $\S \S 2.3 .1$ and 2.4.5);

- As noted previously, diphthongs are considered separately in $\$ 2.4 .3$ below. 
The final column of Table 5 gives the principal active means of transcription for each phoneme, without taking account of representation by zero. The table shows that in the cases of /a/ and /i/ the primary active means of transcribing each vowel is the same for the long and the short variants, consistent with Jongeling's claim. In the cases of $/ \mathrm{e} / \mathrm{/} / \mathrm{o} /$, and $/ \mathrm{u} /$ a difference is observable, although the frequencies are in each case very low, making it difficult to come to a conclusion. What is important to observe, however, is that, while the principal means of transcription appears to be governed primarily by quality rather than quantity, in the cases at least of $/ \mathrm{a} /, / \mathrm{i} /$, and / $\mathrm{u} /$ the long vowel is more likely to be represented than the short vowel, suggesting that those composing the text of the inscriptions were sensitive to distinctions in Latin vowel length. Consider, for example, the representation of $/ \mathrm{i} / \mathrm{in} / \mathrm{kandide} />q^{\varsigma} n d d^{2}($ Labdah N 9, 10) and /fortis/ $>p^{2} r t ⿱ s$ (Hr. Maktar N 83) versus that of /i:/ in /auguri:ne/ $>{ }^{\varepsilon}$ wgryn $^{2}$ (Teboursouk N 13). Similarly, note the contrasting representations of the two / $\mathrm{i} /$ vowels in /wiri:lis/ written wrylš (Hr. Maktar N 94) and of /u/ in /ruifus/ written rwps (Labdah N 13).

We will return to the question of the perception of vowel length on the part of those composing the texts of these inscriptions below, esp.§§ 2.4.3 and 2.4.5. 
Table 5: Latin vowel quality and quantity transcription into Neo-Punic including zero representation (observed token frequencies, percentages in parentheses)

\begin{tabular}{|c|c|c|c|c|c|c|c|c|c|}
\hline & Zero & & & on-Zer & & & & Primary & riptions \\
\hline & $\langle\emptyset\rangle$ & $\left\langle^{c}\right\rangle$ & $\left.<^{\prime}\right\rangle$ & $<\mathrm{h}>$ & $<w>$ & $<y>$ & 苛 & $\begin{array}{l}\text { incl. } \\
\text { zero }\end{array}$ & $\begin{array}{l}\text { excl. } \\
\text { zero }\end{array}$ \\
\hline /a/ & $\begin{array}{c}3 \\
(14)\end{array}$ & $\begin{array}{c}17 \\
(81)\end{array}$ & $\begin{array}{c}1 \\
(5)\end{array}$ & - & - & - & 21 & $\langle c\rangle$ & $<>$ \\
\hline /a:/ & - & $\begin{array}{c}26 \\
(100)\end{array}$ & - & - & - & - & 26 & $\left.<^{c}\right\rangle$ & $<>$ \\
\hline /e/ & $\begin{array}{c}15 \\
(75)\end{array}$ & - & $\begin{array}{c}4 \\
(20)\end{array}$ & $\begin{array}{c}1 \\
(5)\end{array}$ & - & - & 20 & $<\varnothing>$ & $<^{\prime}>$ \\
\hline /e:/ & $\begin{array}{c}6 \\
(60)\end{array}$ & - & $\begin{array}{c}3 \\
(30)\end{array}$ & $\begin{array}{c}1 \\
(10)\end{array}$ & - & - & 10 & $<\emptyset>$ & $<^{\prime}>$ \\
\hline /i/ & $\begin{array}{c}11 \\
(37)\end{array}$ & - & - & - & - & $\begin{array}{c}19 \\
(63)\end{array}$ & 30 & $\begin{array}{c}<y> \\
(<\emptyset>)\end{array}$ & $<y>$ \\
\hline /i:/ & $\begin{array}{c}2 \\
(11)\end{array}$ & - & - & - & - & $\begin{array}{c}16 \\
(89)\end{array}$ & 18 & $<y>$ & $<y>$ \\
\hline /o/ & $\begin{array}{c}8 \\
(80)\end{array}$ & - & $\begin{array}{c}1 \\
(10)\end{array}$ & $\begin{array}{c}1 \\
(10)\end{array}$ & - & - & 10 & $<\varnothing>$ & $<^{\prime}>$ \\
\hline /o:/ & $\begin{array}{c}6 \\
(75)\end{array}$ & - & $\begin{array}{c}2 \\
(25)\end{array}$ & - & - & - & 8 & $<\emptyset>$ & $\left.<^{\prime}\right\rangle$ \\
\hline$/ \mathrm{u} /$ & $\begin{array}{c}23 \\
(88)\end{array}$ & - & - & - & $\begin{array}{c}2 \\
(8)\end{array}$ & $\begin{array}{c}1 \\
(4)\end{array}$ & 26 & $<\emptyset>$ & $\begin{array}{l}<\mathrm{w}>, \\
<\mathrm{y}>\end{array}$ \\
\hline /u:/ & $\begin{array}{c}1 \\
(11)\end{array}$ & - & $\begin{array}{c}4 \\
(44)\end{array}$ & $\begin{array}{c}1 \\
(11)\end{array}$ & $3(33)$ & - & 9 & $\begin{array}{l}<{ }^{\prime}> \\
<\mathrm{w}>\end{array}$ & $\begin{array}{l}<’>, \\
<w>\end{array}$ \\
\hline
\end{tabular}

\subsubsection{Conclusion}

Neo-Punic is at one level unpredictable as to exactly how a given vowel will be represented in a particular inscription. This has been confirmed by our data. The present analysis, however, supports the identification of patterns underlying the surface phenomena. The present study differs from previous ones in that it 
takes account of where a given vowel phoneme is represented by zero. The principal findings are these:

- $\quad / a /$ is represented by $<^{c}>$, regardless of its length;

- The mid vowels /e/ and /o/ are liable to go unrepresented, again regardless of length;

- The high vowel /i/ is more likely than not to be represented whether long or short, and much more so when long;

- The high vowel $/ \mathrm{u} /$ is most likely to be represented when long, and more likely to be unrepresented when short.

This situation can be summarised in the vowel triangles for short and long vowels in Figure 1 andFigure 2, respectively.

Figure 1: Short vowel triangle

$$
\begin{aligned}
& \text { /i/ } \\
& <\mathrm{y}>,(<\emptyset>) \\
& \text { /u/ } \\
& <\emptyset> \\
& \begin{array}{l}
\text { /e/ } \\
<\emptyset>
\end{array} \\
& \text { /o/ } \\
& <\emptyset> \\
& \text { /a/ } \\
& <>
\end{aligned}
$$

Figure 2: Long vowel triangle

$$
\begin{aligned}
& \text { /i:/ } \\
& <y> \\
& \text { /e:/ } \\
& \text { /o:/ } \\
& <\emptyset> \\
& <\emptyset> \\
& \text { /a:/ } \\
& <^{c}>
\end{aligned}
$$

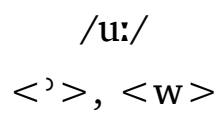


The situation is superficially reminiscent of that seen, for example, in manuscripts representing the Tiberian tradition of Biblical Hebrew (BH), where long $/ \mathrm{i} /$ and $/ \mathrm{u}$ / are more likely to be represented by $\langle\mathrm{y}\rangle$ and $\langle\mathrm{w}\rangle$, respectively, than their short equivalents, and where the mid vowels /e/ and /o/ are less likely to be represented than their respective higher equivalents, $/ \mathrm{i}$ / and $/ \mathrm{u} /$. The main differences between Neo-Punic and $\mathrm{BH}$ are, however, (a) the fact of representation of /a/, which is usually left unrepresented in BH (except word-finally), and (b) the use of $<^{c}>$ to represent /a/, since $<^{c}>$ is not a mater in $\mathrm{BH}$, at least in the Masoretic tradition. ${ }^{5}$

\subsection{Factors Affecting Zero Representation in Neo- Punic}

So far we have considered the manner in which particular phonemes are represented in Neo-Punic writing. We have seen that, with the exception of /a:/, all vowel phonemes may be represented by $\langle\emptyset\rangle$. It is therefore important to consider what factors might affect whether or not a given vowel is represented at all.

In this section, we move on to consider what other factors, apart from vowel quality and quantity, might affect whether or not a vowel is represented. The following variables are considered:

- The position of the Latin stress;

- The position of the relevant syllable in the word.

\footnotetext{
${ }^{5}$ For the possible origins of the use of $\left.<^{c}\right\rangle$ as a mater in Punic, as well as examples of its use as a mater in Samaritan Hebrew and in the Babylonian tradition, see Kerr $(2010,42)$ and references there.
} 


\subsubsection{Position of the Latin Stress}

A priori, apart from quality and quantity, the most obvious factor likely to affect the marking of a vowel, or the lack thereof, is the position of the stress. In Classical Latin, the stress falls on the antepenultimate syllable of the word (or the penultimate if there is no antepenultimate), unless the penultimate syllable is 'heavy', that is, is either closed or contains a long vowel (cf., e.g., Lindsay 1891). For this analysis, the same dataset is used as was at $\$ 2.2 .2$ for the investigation of vowel quality and quantity, with the exception that closed syllables were included, on the grounds that stress is unaffected by vowel length in closed syllables.

The results are given in Table 6 andTable 7. From these it is apparent that the position of the Latin stress has an effect on whether or not a vowel is marked: 71 percent of stressed syllables are marked, while only 36 percent of unstressed ones are.

Table 6: Latin accent: Observed token frequencies

\begin{tabular}{|l|c|c|c|}
\hline & Marked V & Unmarked V & Total \\
\hline Stressed & 96 & 39 & 135 \\
\hline Unstressed & 42 & 75 & 117 \\
\hline Total & 138 & 114 & 252 \\
\hline
\end{tabular}

Table 7: Latin accent: Observed token percentages

\begin{tabular}{|l|c|c|}
\hline & Marked V & Unmarked V \\
\hline Stressed & 71 & 29 \\
\hline Unstressed & 36 & 64 \\
\hline
\end{tabular}

\subsubsection{Syllable Position}

It is generally assumed that Late Punic was oxytonic (cf. Kerr $2010,100)$. Since it is reasonable to suppose that at least some 
speakers would have pronounced Roman names with a Punic rather than a Latin stress, it is interesting to consider whether the absolute syllable position of a vowel has an effect on its zero representation. Table 8, accordingly, gives the token frequencies of vowel marking by syllable position, counting from the final syllable, for words of different syllable lengths. The dataset for this analysis was the same as that used for the analysis at $\$ 2.3 .1$ for the investigation of Latin stress.

Table 8: Frequency of vowel marking by syllable position (percentages in parentheses)

\begin{tabular}{|c|c|c|c|c|c|c|}
\hline \multirow{2}{*}{$\begin{array}{c}\text { Number of } \\
\text { syllables }\end{array}$} & \multirow{2}{*}{ Marked } & \multicolumn{5}{|c|}{ Syllable position counting from final } \\
\hline & & 1 & 2 & 3 & 4 & 5 \\
\hline \multirow{2}{*}{2} & Yes & - & $46(73)$ & & & \\
\hline & No & $28(100)$ & $17(27)$ & & & \\
\hline \multirow{2}{*}{3} & Yes & - & $31(57)$ & $22(50)$ & & \\
\hline & No & $8(100)$ & $23(43)$ & $22(50)$ & & \\
\hline \multirow{2}{*}{4} & Yes & - & $14(88)$ & $10(59)$ & $6(55)$ & \\
\hline & No & $2(100)$ & $2(13)$ & $7(41)$ & $5(45)$ & \\
\hline \multirow[b]{2}{*}{ 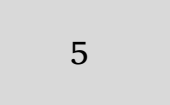 } & Yes & - & $2(100)$ & $2(100)$ & $2(100)$ & $2(100)$ \\
\hline & No & - & - & - & - & - \\
\hline
\end{tabular}

From the table the following trends may be observed, by word length:

- In names of two and four syllables, the second syllable from the end of the word is very likely to be marked (73 percent and 88 percent, respectively). Thus /maker/ spelled $m^{\S} q r$ (Labdah N18) is typical, while $q l r$ for /keler/ (Djebel Mansour N1) is less typical. 
- There are no examples within the corpus of the writing of a vowel occurring in the final syllable (recall again that final vowel tokens were excluded; see §2.2.2).

\subsubsection{Conclusion}

We have seen that three factors may be said to contribute to the likelihood of a given Latin vowel phoneme being represented in the Neo-Punic representation of Roman names, namely:

- Vowel length: Latin long vowels are more likely to be represented than short vowels;

- Presence of the stress: stressed vowels in Latin are more likely to be represented than unstressed ones;

- Syllable position: especially in names of two and four syllables, the vowel of the penultimate syllable is very likely to be represented. The vowel of the final syllable, where the word is spelled terminating in a consonant, is almost never represented.

It is worth considering what principles of Neo-Punic phonology might underlie these observations, especially if word stress is to be linked with the likelihood of vowel marking. Kerr (2010, 100) concludes, on the basis of the Latino- and Greco-Punic inscriptions, that in the Late Punic language:

- All unstressed syllables are treated as short;

- Stressed syllables are treated as long;

- The distinction in vowel quantity was lost.

On this basis, Kerr infers that the stress in Late Punic was on the final syllable. How may this assessment be said to correspond with the evidence presented above? 
It should be emphasised that the present study considers only Latin personal names as rendered into Neo-Punic characters. It is nevertheless interesting to observe that the distribution of vowel marking in Neo-Punic cannot be said to corroborate Kerr's assessment in regard to Late Punic as seen in the Latino- and Greco-Punic inscriptions. If it did, we would expect regularly to see the final vowel of a name with the vowel written, instead of other vowel positions. Furthermore, we would not expect the position of the Latin stress, or the natural length of a vowel in Latin, to have an effect on whether or not a given vowel is represented.

The evidence from the Neo-Punic rendering of Roman names points to two possible conclusions:

1. In the transcription of Roman names, Neo-Punic writers ignored Late Punic stress patterns, but rather followed Latin patterns of pronunciation;

2. Late Punic was not always oxytonic.

If the first is the case, this suggests a fairly high degree of familiarity with Latin phonology on the part of Punic speakers in Roman North Africa. To be sure about this, however, it is necessary to survey the distribution of vowel spellings in Punic words, something that we leave to future work.

\subsection{Implications for the Late Punic Reading of the Latin Vowel System in North Africa}

In this section we assess the implications of the representation of the Latin vowel system in Neo-Punic for the Late Punic reading of the Latin vowel system. This is of particular relevance to the development of the vowel system in Classical Latin (CL), with 
distinctions of both quantity and quality, to that found in early Romance, which has only distinctions of quality.

In the Common Romance (CR) vowel system CL / i/ and /e:/ merge to /e/ on the front axis, while on the back axis /o:/ and $/ \mathrm{u} /$ merge to $/ \mathrm{o} /$. There are notable exceptions to this evolution. In our view, it is worth mentioning the development of the Sardinian varieties, which is supposedly shared by African Latin (see \$2.4.5), where on the front axis CL / $\mathrm{i} /$ / and / $\mathrm{i} /$ merge to /i/, /e:/ and /e/ to /e/, while on the back axis /o/ and /o:/ merge to $/ \mathrm{J} /$, and $/ \mathrm{u} /$ and $/ \mathrm{u} /$ to $/ \mathrm{u} /$. These developments are summarised in Figure 3 and Figure 4 respectively.

Figure 3: Development of the vowel system from CL to CR (adapted from Loporcaro 2011, 115)

\begin{tabular}{l|c|c|c|c|c|c|c}
\hline $\mathrm{CL}$ & /i:/ & /i/ /e:/ & /e/ & /a/ & /o/ & /o:/ /u/ & /u:/ \\
$\mathrm{CR}$ & /i/ & /e/ & $/ \mathrm{e} /$ & /a/ & /o/ & /o/ & /u/ \\
\hline
\end{tabular}

Figure 4: Development of the vowel system from CL to Sardinian (S) (adapted from Loporcaro 2011, 112)

\begin{tabular}{l|c|c|c|c|c}
\hline $\mathrm{CL}$ & /i:/ /i/ & /e:/ /e/ & /a/ & /o/ /o:/ & $/ \mathrm{u} /$ /ui/ \\
$\mathrm{S}$ & $/ \mathrm{i} /$ & $/ \mathrm{e} /$ & /a/ & $/ \mathrm{s} /$ & $/ \mathrm{u} /$ \\
\hline
\end{tabular}

In this context, it is interesting to ask if the Neo-Punic transcription of Latin personal names gives any indication of where North African Latin might have been situated in regard to these developments.

\subsubsection{Front Axis: CL /e/, /e:/, /i/, and /i:/}

Table 9 gives the transcription of the CL front-axis vowels into Neo-Punic. All four phonemes are in some cases transcribed 
$<\emptyset>$. Where they are positively marked, however, there is no overlap between /e, e:/, on the one hand, and /i, i:/, on the other. By contrast, there is clear overlap in the treatment of /e/ and /e:/, with both transcribed by $\langle>\rangle$ and $\langle\emptyset\rangle$ in the corpus. Similarly, /i/ and /i:/ are both transcribed by $\langle y\rangle$ and $\langle\emptyset\rangle$.

On the basis of these data, therefore, we should conclude that any overlap that was perceived by Late Punic speakers in North Africa was between /e/ and /e:/, on the one hand, and /i/ and /i:/, on the other. This situates the North African treatment of these phonemes together with Sardinian and against CR.

Table 9: Neo-Punic transcription of Latin front axis vowels (reproduced from Table 5)

\begin{tabular}{|c|c|c|c|c|c|c|}
\hline & $\langle\emptyset\rangle$ & $\left\langle^{c}\right\rangle$ & $\left\langle^{\prime}\right\rangle$ & $\langle\mathrm{h}\rangle$ & $\langle\mathrm{w}\rangle$ & $\langle\mathrm{y}\rangle$ \\
\hline /e/ & $15(75)$ & - & $4(20)$ & $1(5)$ & - & - \\
\hline /e:/ & $6(60)$ & - & $3(30)$ & $1(10)$ & - & - \\
\hline /i/ & $11(37)$ & - & - & - & - & $19(63)$ \\
\hline /i:/ & $2(11)$ & - & - & - & - & $16(89)$ \\
\hline
\end{tabular}

\subsubsection{Back Axis: CL /o/, /o:/, /u/ and /u:/}

The data for the Neo-Punic treatment of the back-axis vowel phonemes are given in Table 10. It is apparent from these that this case is not so clear cut. As with the front axis, all four phonemes can be zero-marked, and, as noted before, this is considerably more likely in the case of short vowels than in that of long vowels. Unlike on the front axis, however, three of the four phonemes, namely /o/, /o:/, and /u:/, may be actively marked by the same grapheme, $<>>$. The phonemes $/ \mathrm{u}$, u:/ do though differ 
from /o, o:/, in that the former may be denoted by $\langle\mathrm{w}\rangle$, while the latter may not.

We may conclude, then, that there is overlap in the treatment of all four vowel phonemes on the back axis, but that $/ \mathrm{u}$ / and /u:/ are distinguished by being able to be transcribed by $<\mathrm{w}>$. As with the front axis, therefore, the higher vowels $/ \mathrm{u} /$ and /u:/ pattern together against the lower vowels /o/ and /o:/ in an important respect.

Table 10: Neo-Punic transcription of Latin back axis vowels (reproduced from Table 5)

\begin{tabular}{|c|c|c|c|c|c|c|}
\hline & $\langle\emptyset\rangle$ & $\left\langle{ }^{\mathrm{c}}\right\rangle$ & $\left\langle^{\prime}\right\rangle$ & $\langle\mathrm{h}\rangle$ & $\langle\mathrm{w}\rangle$ & $\langle\mathrm{y}\rangle$ \\
\hline /o/ & $8(80)$ & - & $1(10)$ & $1(10)$ & - & - \\
\hline /o:/ & $6(75)$ & - & $2(25)$ & - & - & - \\
\hline /u/ & $23(88)$ & - & - & - & $2(8)$ & $1(4)$ \\
\hline /u:/ & $1(11)$ & - & $4(44)$ & $1(11)$ & $3(33)$ & - \\
\hline
\end{tabular}

\subsubsection{Diphthongs}

There is little evidence for monophthongisation of diphthongs in the Neo-Punic corpus (cf. Kerr 2010, 58). Two Latin diphthongs are attested in the set of names under consideration for this paper, /au/ and /ae/. The distribution of transcriptions is given in Table 11. From this it is worth noting that:

1. /au/ shows no sign of monophthongisation;

2. /ae/ is similar, but in one case $q^{\prime} q l y$, for the name Caecilius (Sidi Ali Belkassem N 1), is marked as a monophthong, as $\left.<^{c}\right\rangle$, suggesting /a/. 
Table 11: Rendering of diphthongs into Neo-Punic

\begin{tabular}{|l|c|c|c|}
\hline & $\left.<^{\mathrm{c}}\right\rangle$ & $<^{\mathrm{c}} \mathrm{w}>$ & $\left\langle^{\mathrm{c}} \mathrm{y}\right\rangle$ \\
\hline /ae/ & 1 & - & 6 \\
\hline /au/ & - & 12 & - \\
\hline
\end{tabular}

\subsubsection{Distinctions in Vowel Length}

The evidence provided so far is consistent with a situation closer to that seen in Sardinian Romance than in CR. The evidence against development in the direction of CR is particularly strong in the case of the front axis, although it can also be seen on the back axis insofar as /u, u:/, but not /o, o:/, may be represented by $\langle\mathrm{w}>$. Ultimately, however, the Sardinian system loses vowel length distinctions. What evidence may there be for the North African system also losing vowel distinctions?

We saw above (\$2.2.2) that short vowels are in general less likely to be actively marked than long vowels. Table 12 summarises the data from Table 5, giving the percentage of instances for each phoneme where the phoneme is marked. In general, long vowels are marked in 79 percent of the tokens, while short vowels are marked in 44 percent of the tokens, although particular behaviour is heavily dependent on vowel quality. It would seem on the face of it that Late Punic speakers were sensitive to distinctions in vowel length in Latin names. It would follow that North African Latin had not yet lost distinctions in vowel length by the second century CE.

However, it is important to establish whether vowel length is the key variable, or whether another factor might be primarily 
responsible for the distribution. In particular, in view of the phenomenon of open syllable lengthening in North African Latin, that is, the phenomenon whereby vowels in stressed open syllables are lengthened (see Loporcaro 2011, 52), we should consider how vowel quantity and stress co-vary. It is to this issue that we turn in the next section.

Table 12: Marking of distinctions in vowel length by phoneme

\begin{tabular}{|l|c|c|c|c|}
\hline & Zero & Marked V & Total & \% marked \\
\hline /a/ & 3 & 18 & 21 & 86 \\
\hline /e/ & 15 & 5 & 20 & 25 \\
\hline /i/ & 11 & 19 & 20 & 63 \\
\hline /o/ & 8 & 2 & 10 & 20 \\
\hline /u/ & 23 & 3 & 26 & 12 \\
\hline Subtotal & 60 & 47 & 107 & 44 \\
\hline /a:/ & - & 26 & 26 & 100 \\
\hline /e:/ & 6 & 4 & 10 & 40 \\
\hline /i:/ & 2 & 16 & 18 & 89 \\
\hline /o:/ & 6 & 2 & 8 & 25 \\
\hline /u:/ & 1 & 8 & 9 & 89 \\
\hline Subtotal & 15 & 56 & 71 & 79 \\
\hline Total & 75 & 103 & 178 & 58 \\
\hline
\end{tabular}

\subsubsection{Open Syllable Lengthening}

The testimony of authors from late antiquity suggests that vowellength distinctions were lost in North African Latin (Loporcaro 2011, 55ff.). Thus Augustine (De doctr. christ. IV, 10, 24; for text see, e.g., Bruder 1838) reports that uneducated African speakers 
could not perceive the difference between $\breve{s}$ (sum) 'bone' and $\bar{o} s$ 'mouth'; similarly, Consentius (Keil 1868, 5:392), noted that African speakers were in the habit of lengthening short vowels, such as in ['pi:per] for CL pŭper ['piper] 'pepper'. ${ }^{6}$ These testimonies are supported by Herman (1982), where the comparison between the errors on stressed and unstressed vowels in metrical inscriptions from Africa (first-fourth centuries CE) and from Rome point to an early loss of vowel quantity in African Latin. It is, therefore, interesting to consider whether there may be said to be evidence for this development already in the Neo-Punic material.

There is localised evidence of this having happened in the transcription of Latin names in Neo-Punic, such as in the following examples:

- $<\mathrm{s}^{\mathrm{S} t \mathrm{r}}>$ for CLat. /'satur/, suggesting ['sa:tur] (Hr. Maktar N29)

- $\quad<$ plyql $^{\mathrm{I}}>$ for CLat. /fe'likula/ > [fe'li:kula] (Labdah N47)

Another inscription showing similar tendencies is El-Amruni N1, where we have $p w d n s$ for the name /pudens/, perhaps suggesting a pronunciation along the lines of ['pu:dens]. However, other names in this inscription are spelled plene, e.g.,

\footnotetext{
${ }^{6}$ For a more detailed discussion of the various interpretations provided for these passages, see Loporcaro (2011, 55ff.). Following Loporcaro's interpretation, it is our opinion that Consentius referred specifically to vowel length, as shown by the choice of the technical terms correpta and producta; similarly, we hypothesise that Augustine referred to vowel lengthening in African Latin, even though expressing a negative sociophonetic evaluation.
} 
/se've:rus/ spelled $\check{s}^{2} w^{2}<w^{2}>\mid r^{2}$. Accordingly, the spelling $p w d n \check{s}$ may find its explanation not so much in North African phonology, but in the plene spelling practices of this particular inscription.

There is, furthermore, evidence for this development on the scale of the whole corpus, as may be seen in Table 13 and Table 14. Here the same dataset was used as that for $\S 2.2 .2$ for the investigation into vowel quality and quantity.

Table 13: Latin stress and length in syllables of the shape CV(C): observed token frequencies

\begin{tabular}{|l|l|c|c|c|}
\hline \multicolumn{2}{|c|}{} & Marked V & Zero-marked V & Total \\
\hline \multirow{3}{*}{ Stressed } & Long & 49 & 10 & 59 \\
\cline { 2 - 5 } & Short & 18 & 5 & 23 \\
\cline { 2 - 5 } & Subtotal & 67 & 15 & 82 \\
\hline \multirow{3}{*}{ Unstressed } & Long & 7 & 5 & 12 \\
\cline { 2 - 5 } & Short & 29 & 55 & 84 \\
\cline { 2 - 5 } & Subtotal & 36 & 60 & 96 \\
\hline \multicolumn{2}{|c|}{ Total } & 103 & 75 & 178 \\
\hline
\end{tabular}

Table 14: Latin accent: observed token percentages

\begin{tabular}{|l|l|c|c|}
\hline \multicolumn{2}{|c|}{} & Marked V & Zero-marked V \\
\hline \multirow{2}{*}{ Stressed } & Long & 83 & 17 \\
\cline { 2 - 4 } & Short & 78 & 22 \\
\hline \multirow{2}{*}{ Unstressed } & Long & 58 & 42 \\
\cline { 2 - 4 } & Short & 35 & 65 \\
\hline
\end{tabular}

We find that long stressed vowels are marked in 83 percent of token instances, while short stressed vowels are marked in 78 percent of token instances, indicating that the natural length of 
the vowel in CL does not have a great effect. By contrast, the effect of the stress position is significant. In particular, short unstressed vowels are marked in only 35 percent of token instances, while short stressed vowels are marked in 78 percent of token instances.

How may this finding be said to relate to that in $\S 2.4 .4$ above, where it was found that vowel quantity in CL has an important effect on whether or not a vowel is represented? It is important to recognise that the greater part of the stressed open syllables are long (59 out of 82,72 percent), while an even greater part of the unstressed syllables are short (84 out of 96,88 percent). If stressed vowels in open syllables are more likely to be written than unstressed ones, we should expect to find that more long vowels are written than short vowels simply because of this distribution. However, the fact that nearly the same proportion of stressed short vowels in open syllables are written as stressed long vowels points to stress being the determining variable, at least in open syllables.

This finding in turn provides evidence for early open syllable lengthening in North African Latin, as put forward by Herman (1982). Herman concludes that open syllable lengthening was established in North African Latin by at least the fourth century CE. The Neo-Punic inscriptions, as we saw earlier, are generally dated between the first century BCE and the second century CE. We, therefore, interpret the Neo-Punic evidence as indicative of open syllable lengthening occurring by at least the second century CE. 


\subsubsection{Conclusion}

The significance of these results for the interpretation of the Latin vowel system on the basis of Neo-Punic is as follows. The evidence presented here points to a system closer to that seen in Sardinian than in CR. This is clearest on the front axis, where there is almost no overlap in the positive marking of /e, e:/ and /i, i:/, but clear overlap in the marking of /e/ and /e:/, on the one hand, and /i/ and /i:/, on the other. On the back axis this is less clear, with overlap in the marking of /o, o:/ and /u, u:/. Nevertheless, /u, u:/ are distinguished from /o, o:/ in that it can be marked by $\langle\mathrm{w}\rangle$. When, however, the stress and the length of the vowel were taken into account, evidence was provided that those writing inscription texts were more sensitive to Latin stress than to distinctions in vowel length, supporting the notion that the North African Latin vowel system may have begun to lose distinctions in vowel length by the second century CE.

As will be shown in the next section, these data are consistent with the results of the analysis of a corpus of Latin inscriptions from Sardinia, which point to a maintaining of the qualitative differences between /i/, /i:/ and /e, e:/ on the front axis and between /o, o:/ and /u, u:/ on the back axis.

\subsection{SARDINIA}

\subsection{Introduction}

As outlined in $\S 2.4$, the Sardinian vowel system lost distinctive vowel quantity, but the mergers of /i, e:/ and / $\mathrm{u}$, o:/ typical of the $\mathrm{CR}$ vowel system did not occur. 
Scholars have long argued about the causes of this difference. Traditionally, it is believed that the Sardinian vowel system was conservative, since Sardinia was an isolated area, and, therefore, more likely to show archaic features (see, e.g., Lausberg 1971, 203ff.). More recently, however, some scholars have suggested that this vowel system could instead be an innovation. In particular, Fanciullo (1992) suggested that the peculiar outcome of the Sardinian vowel system could be due to substratum effects, i.e., the inhabitants' inability to perceive the opposition between the long and short counterparts of the phonemes (see also Lupinu 2000, 20).

In the light of this suggestion, given the similar outcomes of the Latin vowel systems in Sardinia and Africa (§2.4), it is worth examining the possibility of interference between the Latin and the Late Punic vowel systems, establishing whether the system which emerges from the analysis of Neo-Punic inscriptions described in $\S 2$ is consistent with the data from Latin inscriptions from Sardinia.

For these reasons, we will first take into account the archaeological and historical sources that point to a strong presence of Latin and Neo-Punic bilingual speakers in Roman Sardinia. We will then examine the vowel alternations $\langle\mathrm{e}\rangle,\langle\mathrm{i}\rangle /<\mathrm{o}\rangle$, $<v>$ in the Latin inscriptions from the island, in order to establish whether these texts foreshadow the development of the Sardinian vowel system. As shown, e.g., by Allen $(1978,49)$, the use of $\langle\mathrm{e}>$ for $<\mathrm{i}\rangle$ (e.g., menus for minus) and $\langle\mathrm{o}\rangle$ for $\langle\mathrm{v}\rangle$ (e.g., colomnas for columnas) in Latin inscriptions could be due to 
a qualitative similarity of Lat. /i/ and /e:/ from early times. ${ }^{7}$ Our hypothesis is that, if evidence of this phenomenon can be found in Sardinia, this would point to the existence of a vowel system of the CR type in Sardinia. Conversely, the lack of such evidence would point to a system closer to that found in North Africa.

\subsection{Neo-Punic and Latin in Sardinia}

Before the Roman conquest of the island, Sardinia had been under the hegemony of Carthage already from the late sixth century BCE (Roppa 2015, 257). As shown by several historical and archaeological sources, the cultural influence of Carthage was significant on the island: in the first treaty between Rome and Carthage (ca. 509 BCE), Sardinia is described as tightly controlled by the Punics. Later, Diodorus Siculus reports that grain supplies were sent from Sardinia to Carthaginian troops in 480 BCE and 396-395 BCE (Roppa 2015, 262). In the second treaty between the two powers (ca. 348 BCE), Sardinia was under the strict hegemony of Carthage and, indeed, commerce between Rome and the island was forbidden (Mastino 1985, 29-30). From the point of view of archaeology, the documentation points to a Sardo-Punic culture in this period, with variously organised local communities, such as the agricultural communities of Neapolis, Nora, and Monte Sirai, along with their hinterlands (Roppa 2015, 26779).

For this reason, the label 'Punic' is traditionally adopted to refer to the period between the sixth century BCE and the Roman

\footnotetext{
${ }^{7}$ On this subject see also, among others, Leumann $(1977,45,51)$ and, more recently, Adams $(2013,43)$ and Loporcaro (2011, 57-59).
} 
occupation of Sardinia in 238 BCE. The Punic influence in Sardinia, however, is not limited to this period: in fact, under the control of Rome, the relationship with the province of Africa was strong, thanks to the geographical proximity of the capital Karales (nowadays Cagliari) to Carthage (ca. 1500 stadia, according to Pliny the Elder; see Mastino 1985, 57).

During the Roman occupation, and even later, several deportations of Africans to Sardinia are attested, such as the four thousand freedmen sent by Sejanus in $19 \mathrm{CE}$ and the Mauri sent to the island by the Vandals in the fifth century CE (Mastino 1985, 36-37). Moreover, the archaeological evidence points to a survival of the Punic traditions in Sardinia during the Roman occupation, which extended to several domains, including linguistic, religious, onomastic, juridical, and administrative (Mastino 1985, 36). Indeed, Punic influence was so deeply rooted that some words belonging to modern Sardinian varieties have a Punic origin, e.g., tsíppiri 'rosemary', mittsa 'spring', and tsikkiría 'dill' (Paulis 1990, 617; Wagner 1997, 158ff.; Pisano 2017, 399).

Evidence of Punic influence on the island comes in several forms. First, a significant number of Punic and Neo-Punic inscriptions have been found there, dating from the end of the ninth century BCE all the way to the second century CE (Adams 2003, 209; Rovai 2015, 198). Hence, it is reasonable to suppose that Punic and Neo-Punic were spoken on the island, even after the destruction of Carthage, at least until the second century CE. Moreover, the bilingualism of the inhabitants of Sardinia is attested by the presence of bi- and trilingual inscriptions featuring 
Latin and Neo-Punic, such as the well-known trilingual inscription from San Nicolò Gerrei (CIL X 7856, first half of the second century BCE), featuring Latin, Greek, and Neo-Punic. As illustrated by Adams (2003, 210-11), this inscription testifies to the fact that Late Punic was still the dominant language in this area, since the Neo-Punic text is the most informative one, with the reference to the weight and the content of the offering, as well as to the date.

Secondly, as demonstrated by van Dommelen (1998, 30), the archaeological record from the first centuries of the Roman occupation in Sardinia is Punic in nature, whereas Roman material culture is almost absent. This is the case, for example, in southern Arborèa, where Roman products from the third and second centuries BCE are scarcely attested, whereas the majority of the local pottery (e.g., commercial amphorae, kitchenware) follows Punic and Neo-Punic models (van Dommelen 1998, 39). Similarly, imported Roman objects are virtually absent in the burial rites held in Bidd'e Cresia (Central Campidano) and in the ritual offerings found in the nuraghe of Genna Maria, which show a "clear sense of Punic cultural identity" (van Dommelen 1998, 42).

Thirdly, there is evidence from the juridical/political domain. Sufetes are attested in Sardinia until at least the first century BCE, such as in Karales, Sulci, Neapolis, Tharros, and even later in Bitia: these Punic magistrates are well attested in Africa as well, at least up to the Imperial period (Mastino 1985, 69-71). As far as religion is concerned, several Punic deities were worshipped in Sardinia, such as Tanit, Melqart, and Eshmun Merre 
(Mastino 1985, 78-79). Moreover, a close examination of the inscriptions from the island reveals a large number of African names: as highlighted by Mastino (1985, 85ff.), drawing on the results of Rowland (1973), the majority of the anthroponyms found in Sardinia can be traced back to African families or Punic provinces.

Finally, it is worth noting that Punic cultural identity in Sardinia was still recognised in the first century BCE: this attitude is demonstrated well by Cicero's Pro Scauro $(19,45)$, where Sardinians were depicted as sons of Africa (Africa ipsa parens illa Sardiniae) in his defence of the corrupt ex-governor of Sardinia, M. Aemilius Scaurus (van Dommelen 1998, 45; see also, among others, Mastino 1985, 34-35).

In conclusion, the archaeological and historical sources at our disposal show strong Punic influence until well after the Roman conquest of the island; moreover, the analysis of the bi- and trilingual inscriptions from Sardinia illustrated above points to a strong presence of Latin and Neo-Punic bilingual speakers, at least until the second century CE. For these reasons, it is reasonable to take account of the North African Neo-Punic evidence in order to better understand the development of the Sardinian vowel system.

\subsection{Vowels in Sardinian Latin: Previous Research}

The possible relevance of the North African situation has not been taken into account in previous linguistic analysis of the inscriptions from Sardinia. The vowel alternations $\langle\mathrm{e}\rangle,\langle\mathrm{i}\rangle /$ $<\mathrm{o}\rangle,\langle\mathrm{v}\rangle$, however, have been partially analysed by Herman 
(1985, 2000) and Lupinu (2000). Their results show a conservative vowel system in Sardinia, with only a few vowel mergers.

First, Herman (1985) examined the vowel alternations occurring in Latin inscriptions from the island dating back to the third and fourth centuries CE. The results of the study show a conservative vowel system, especially in stressed syllables, which seems to foreshadow the Romance outcome of the Sardinian varieties. This is particularly evident through comparison with other regions of the Empire, such as Gallia Narbonensis, where the vowel alternations examined by Herman can be found in both stressed and unstressed syllables. These results are confirmed by the qualitative analysis performed by Lupinu (2000) on the Christian inscriptions, which point to a conservative vowel system.

Finally, Herman (2000) compared the number of vocalic misspellings in the Christian inscriptions from Sardinia with the number of consonantal misspellings. Again, the results point to a scarcity of vowel alternations: only 16 percent of the misspellings involve vowels, and this percentage is significantly lower than the number of vocalic misspellings found in other regions, such as Regio IX (76 percent) and Regio XI (71 percent; see Herman 2000, 129-30).

The studies summarised so far are remarkable and yield interesting results. For this reason, we have run a more complete quantitative analysis on all the dated Latin inscriptions from the island, with the aim of casting light on the Romance development of the Sardinian vowel system. As we will see in the following section, the error rate has been calculated against the corresponding correct spellings (i.e., occurrences of $<\mathrm{i}>$ for $/ \mathrm{i} /,<\mathrm{e}>$ for 
/e/, etc.). In this way, it is possible to provide percentages that will enable us to verify whether the scarcity of vowel alternations from Sardinia is due to the relatively limited number of tokens with respect to other areas of the Empire. Moreover, by taking into account the dating of the inscriptions and extending the analysis to all the available dated texts from Sardinia it will be possible to trace the diachronic development of the process. Finally, the literacy level of those involved in the crafting of the inscriptions has been considered, in order to exclude the possibility that the absence of misspellings could be due to a high degree of literacy among the writers.

In order to be able to perform such an analysis, an annotated epigraphic corpus containing all the available inscriptions from Sardinia has been built, as will be shown in the following paragraph.

\subsection{The Corpus}

The analysis presented in this section was performed on an annotated epigraphic corpus that includes Latin inscriptions from Sardinia dating between the first century BCE and the seventh century CE. The text data have been annotated with extra- and metalinguistic information, which allows us to analyse spelling (and possibly phonetic-phonological) variants in Sardinian inscriptions and to interpret them with reference to variables, such as the dating and the provenance of the texts. It will form part of the CLASSES database (Corpus for Latin Sociolinguistic Studies 
on Epigraphic textS), ${ }^{8}$ developed at the Department of Philology, Literature and Linguistics of the University of Pisa, which gathers non-literary Latin texts (inscriptions, letters, writing tablets) of different provinces of the Roman Empire. ${ }^{9}$

The epigraphic texts from Sardinia have been selected through the examination of the main collections of Latin inscriptions from the island, i.e., Corpus Inscriptionum Latinarum $X$ (fasc. I, section Pars posterior inscriptiones Siciliae et Sardiniae comprehendens); Ephemeris Epigraphica VIII (section Additamenta ad Corporis vol. IX et X); Giovanna Sotgiu's two volumes (1961; 1968), Iscrizioni Latine della Sardegna (Supplemento al Corpus Inscriptionum Latinarum, $X$ e all'Ephemeris Epigraphica, VIII), and the more recent collection by Sotgiu (1988). Among the texts available for this province, the inscriptions considered not to be relevant for linguistic analysis have been excluded, i.e., inscriptions consisting of only single letters and initials, fragmentary texts, as well as those written entirely in other languages (e.g., Greek).

The resulting corpus contains 616 inscriptions, for a total number of 9,379 tokens. The texts are found mainly along the coast, the so-called 'Romània costiera', where the main Roman cities were built (see Mastino 2002, 63).

\footnotetext{
${ }^{8}$ The database is available online: http://classes-latin-linguistics.fileli. unipi.it/.

${ }^{9}$ At the moment, the database contains more than 1200 inscriptions, mainly from Rome and Central Italy, 200 ink-written tablets from Vindolanda, and 219 letters from the North-African and Near-East areas. For a more detailed illustration of the corpus, see Marotta $(2015 ; 2016)$ and De Felice et al. (2015).
} 
The innovative aspect of our corpus is the annotation of linguistic phenomena, which focuses on phonetic aspects of the language. Spellings that do not conform to Classical norms were manually retrieved and, following the same criteria adopted for CLaSSES, were classified according to the type of variation phenomena that distinguish them from corresponding classical equivalents. Finally, each token was annotated with extralinguistic information regarding the place of provenance and the dating of each inscription. In this way, it is possible to relate these variables to the graphic variants identified.

This corpus will enable us to shed light on the vowel alternations in the inscriptions from the first century BCE to the seventh $\mathrm{CE}$, as will be shown in the following paragraph.

\subsection{Latin Vowels in the Inscriptions from Sardinia}

The survey presented in this section focuses on the confusion between $\langle\mathrm{e}>/<\mathrm{i}\rangle$ and $\langle\mathrm{o}\rangle /<\mathrm{v}\rangle$ in the corpus. The analysis was limited to dated inscriptions in order to trace the diachronic development of the phenomenon on the island. However, we do not exclude the possibility of extending the investigation to undated inscriptions in a future study.

\subsubsection{Error Rate}

In Sardinia, the number of vowel alternations is extremely low, especially if their frequency is measured against the number of the corresponding correct spellings. As shown in Table 15, only 
eighteen tokens show $<\mathrm{e}>$ for $<\mathrm{i}>$, which amount to 0.22 percent; on the back axis, there are only three tokens showing $<0>$ for $<\mathrm{v}\rangle$ (0.08 percent).

Similarly, our corpus shows a very low number of deviant spellings involving the mid-high vowels (Table 16): on the front axis, five tokens show $<\mathrm{i}>$ for $<\mathrm{e}>$ ( 0.11 percent); on the back axis, the number of occurrences of $\langle\mathrm{v}\rangle$ for $\langle\mathrm{o}\rangle$ amounts to seven tokens ( 0.21 percent).

Table 15: Graphic representation of $/ \overline{\mathrm{l}} /, / \overline{\bar{u}} /$ in Sardinia

\begin{tabular}{|c|c|c|c|c|c|}
\hline \multicolumn{3}{|c|}{$<\mathrm{i}>$} & \multicolumn{3}{c|}{$<\mathrm{v}>$} \\
\hline Grapheme & Tokens & $\%$ & Grapheme & Tokens & $\%$ \\
\hline$<\mathrm{e}>$ & 18 & 0.22 & $<\mathrm{o}>$ & 3 & 0.08 \\
\hline$<\mathrm{i}>$ & 8178 & 99.78 & $<\mathrm{v}>$ & 3839 & 99.92 \\
\hline Total & 8196 & 100 & Total & 3842 & 100 \\
\hline
\end{tabular}

Table 16: Graphic representation of $/ \check{\bar{e} /} /, / \overline{\bar{o}} /$ in Sardinia

\begin{tabular}{|c|c|c|c|c|c|}
\hline \multicolumn{3}{|c|}{$<\mathrm{e}>$} & \multicolumn{3}{c|}{$<\mathrm{o}>$} \\
\hline Grapheme & Tokens & $\%$ & Grapheme & Tokens & $\%$ \\
\hline$<\mathrm{i}>$ & 5 & 0.11 & $<\mathrm{v}>$ & 7 & 0.21 \\
\hline$<\mathrm{e}>$ & 4608 & 99.89 & $<\mathrm{o}>$ & 3388 & 99.79 \\
\hline Total & 4613 & 100 & Total & 3395 & 100 \\
\hline
\end{tabular}

Therefore, even if the total number of Sardinian inscriptions is considerably lower than in other regions of the Empire (see §3.3), these percentages show that the vowel alternations under analysis are very rare on the island. 
For this reason, the mergers between /i, e:/ and / $\mathrm{u}$, o:/ seem not to have taken place in Sardinia in the broad time frame covered by our corpus: this trend seems thus to foreshadow the Romance development of the Sardinian varieties (§2.4).

\subsubsection{Literacy}

As shown in the previous paragraphs, the methodology of calculating the error rate as a percentage against the total number of correct spellings can be useful for the analysis of a relatively small corpus such as the Sardinian one.

This procedure, however, does not account for an important variable: the level of literacy of those involved in the crafting of the inscriptions. The literacy level is of great importance to avoid conclusions based on 'negative evidence'. In principle, if the level of literacy of the writers was found to be high, the lack of misspellings in the inscriptions should not be taken as a reflection of their pronunciation, since the graphemes used would reflect instead their knowledge of classical norms.

In order to exclude this possibility, the percentage of inscriptions which do not show uncertainty regarding the vowels under analysis, but at the same time show other types of misspellings, has been calculated (Table 17). ${ }^{10}$

${ }^{10}$ Examples of other types of misspellings taken into account are the following: deletion of consonants (final $-s,-m$, $-t$, etc.), insertion of vowels or consonants, monophthongisation, dissimilation, non-etymological gemination, degemination, confusion between voiced and voiceless stops, loss or insertion of aspiration, confusion between $<b>$ and $<\mathrm{v}>$. 
Table 17: Percentage of inscriptions showing misspellings other than vowel alternations

\begin{tabular}{|c|c|c|}
\hline $\begin{array}{c}\text { Inscriptions showing other } \\
\text { types of misspellings }\end{array}$ & 281 & 47 \\
\hline $\begin{array}{c}\text { Inscriptions not showing other } \\
\text { types of misspellings }\end{array}$ & 317 & 53 \\
\hline Total & 598 & 100 \\
\hline
\end{tabular}

As shown in the Table, in nearly half of the inscriptions (47 percent) where the graphic representation of the vowels /i/, /e/, /o/, and $/ \mathrm{u}$ / follows the Classical norms, there are other types of misspellings. Thus, in at least half of the cases, the lack of vowel alternations seems to be due to something other than the writer's high educational level.

These data show therefore that those involved in the crafting of the inscriptions had uncertainties at other points of the language, but not regarding the vowel system. Thus, it is possible to hypothesise that the correct spelling of the vowels indicates at least a distinction between /i, e:/ and / $\mathrm{u}, \mathrm{o}:$ / in Sardinia until the seventh century CE.

\subsubsection{Stress}

Lexical stress has also been taken as a variable in this analysis, in order to verify whether the vowel qualities are better preserved under stress.

For this reason, the proportion of the vowel mergers occurring in stressed and unstressed syllables has been calculated, as shown in Table 18. 
Table 18: Vowel alternations and lexical stress

\begin{tabular}{|c|c|c|}
\hline Prosodic context & Tokens & $\%$ \\
\hline Stressed syllable & 4 & 12 \\
\hline Unstressed syllable & 29 & 88 \\
\hline Total & 33 & 100 \\
\hline
\end{tabular}

The results of our analysis show that vowel alternations affect predominantly unstressed syllables (88 percent), whereas vowel qualities are better preserved under stress (where only 12 percent show evidence of merger). Therefore, the proportion of vowel mergers in stressed versus unstressed syllables is 1:7.3. According to Herman $(1990,23)$, in a given Latin text the proportion of stressed syllables to unstressed is $1: 2.5$. It is thus possible to state that in our corpus vowel quality is better preserved under stress: this picture is consistent with the results of the qualitative analysis of the tokens, which are discussed in the following section.

\subsubsection{Qualitative Analysis}

The picture illustrated so far is further confirmed by a qualitative analysis of the forms showing the alternations: as partly shown by Herman (1985) and Lupinu (2000), most of the instances may not be considered phonetic spellings. This applies, for example, to the case of the nominative tubicin (for tubicen 'trumpeter'), which could easily be explained as a confusion with oblique cases such as the accusative tubicinem; similarly, the twelve alternations involving the morpheme -et (for -it) of the 3rd person singular of the present tense (third conjugation), such as in ducet 
'he/she leads', adducet 'he/she leads', quiescet 'he/she rests', and requiescet 'he/she rests', could be due to the reorganisation of the verbal system (Herman 1985). As far as nominal inflection is concerned, a morphosyntactic explanation can be proposed for the form nepus (for nepos 'grandson'), which may be due to confusion between the ending of the third and second declension (Lupinu 2000, 29); similarly, the ablatives potestati (for potestate 'power', abl. sing.) and paci (for pace 'peace', abl. sing.) may be explained as confusion with the dative ending or with the ablative ending of $-i$ - stems (such as the abl. animali from animal, animalis 'animal'; see also Lupinu 2000, 24). Finally, anus (for annos 'years' acc. plur., in CIL X 7767, fifth century CE) may be due to a confusion between the nominative and the accusative form (Herman 1985).

In conclusion, half of the cases of vocalic confusion found in the corpus (seventeen of thirty-three) have a non-phonetic explanation. If such doubtful instances are excluded, our corpus shows only sixteen vocalic misspellings out of 20,013 instances of standard spellings for the vowels examined. Therefore, the qualitative analysis reinforces the conclusions put forward in the preceding sections, pointing to preservation of the qualitative difference between /i, e:/ and /u, o:/ in Sardinia.

\subsection{Transcription of Roman Names into Neo-Punic in Sardinia}

The picture of qualitative difference between /i, e:/ and / $\mathrm{u}, \mathrm{o:} /$ is further supported, at least until the second century CE, by the two Neo-Punic inscriptions from Sardinia involving Roman 
names in Jongeling (2008). The names given in Table 19 are those without textual problems and where the vowel quantities of the Latin name could be found: ${ }^{11}$

Table 19: Roman names in Neo-Punic inscriptions from Sardinia

\begin{tabular}{|lll|}
\hline Roman name & $\begin{array}{l}\text { Neo-Punic } \\
\text { transcription }\end{array}$ & Inscription \\
\hline /anto:ni:nus/ & ${ }^{\varsigma}$ nṭynh & Chia N1 \\
/aure:lius/ & ${ }^{\varsigma}$ wrhly & Chia N1 \\
/kaesar/ & $q^{\varsigma} y s r$ & Chia N1 \\
/fe:liks/ & phlys & Chia N1 \\
/pompe:ius/ & $p^{\text {p} m p^{\varsigma} y}$ & Chia N1 \\
/sa:turni:nus/ & $s^{\text {strnynh }}$ & Chia N1 \\
/fe:liks/ & plks & S. Antioco N2 \\
/pullius/ & phly ${ }^{\text {?12 }}$ & S. Antioco N2 \\
\hline
\end{tabular}

The two inscriptions appear to adopt different spelling practices. In particular, in Chia N1 there is a predominance of plene spellings. The spelling phlys for /fe:liks/ in Chia N1 is in fact the only example in the whole corpus where a disyllabic Roman name ending in a consonant has the vowel of the final syllable spelled out. By contrast, the same name is spelled without vowels as plks in S. Antioco N2. There are also similarities, however: in particular, the prevalent use of $\langle\mathrm{h}\rangle$, used at Chia $\mathrm{N} 1$ to represent /e:/, but /u/ at S. Antioco.

\footnotetext{
${ }^{11}$ The quantities of / pedukeius/ spelled $p h d w q^{\varsigma} y h$ in Chia N 1 could not be found.

${ }^{12}$ The letter $y$ in this transcription is marked as uncertain.
} 
Of particular interest for us, however, is the treatment of the phonemes /i/, /i:/, /e/ and /e:/, where /e/ phonemes are rigidly distinguished from / $\mathrm{i} /$ phonemes. What is more, Chia $\mathrm{N} 1$ can be dated to the rule either of Marcus Aurelius, who reigned between 161 and $180 \mathrm{CE}$, or of Caracalla, who reigned between 198 and 217 CE (Jongeling 2008, 275; for dates see Rutherford 1996 and Birley 1996). This evidence is consistent with both the lack of merging of /e:/ and $/ \tilde{l} /$ in Sardinian Latin at least before these dates and the treatment of Roman names in North Africa in the Neo-Punic inscriptions.

\subsection{Conclusion}

On the basis of the analysis provided in the previous paragraphs, the graphemic representation of vowels in Latin and Neo-Punic inscriptions from Sardinia foreshadows the Romance outcome of the Sardinian vowel system. The vowel alternations which might point to a 'Common Romance' vowel system are rare on the island, even in late texts: the graphemes used to represent /i, e:/ and /u, o:/ are, therefore, kept distinct in Sardinia until the seventh century CE, a finding which is consistent with the representation of vowels occurring in Roman names in the Neo-Punic inscriptions from North Africa. This is particularly evident when calculating the error rate as a percentage against the corresponding rate of correct spellings (§3.5.1). Moreover, a more finegrained qualitative analysis shows that the few alternations found in the corpus are not likely to represent phonetic spellings (§3.5.4) and, in general, vowel qualities are better preserved un- 
der stress (§3.5.3). Finally, the absence of alternations is not always due to a high level of literacy among writers (§3.5.2): for this reason, our data may be taken as a reflection of the pronunciation of those involved in the crafting of the inscriptions. In conclusion, the correct spelling of vowels in our corpus indicates a distinction between /i, e:/ and / $\mathrm{u}, \mathrm{o}: /$ in Sardinia until at least the seventh century CE. Although the Neo-Punic data only go up (approximately) to the second century CE, the findings are consistent at least to that date.

The results of the surveys given here point to a similar system shared by Sardinian Latin (first-seventh centuries CE) and North African Latin (at least up to the second century CE). In both cases, our analysis shows overlap between the graphemes used to represent /e, e:/ and /i, i:/ and between /o, o:/ and /u, u:/, respectively, whereas vowel confusions typical of a Common Romance development are virtually absent. Therefore, our data foreshadow the Romance outcome of the Sardinian vowel system and are consistent with the alleged development of the African Latin vowel system. On the basis of this we suggested that contact between Sardinia and North Africa until well into the Roman period may be responsible for the development of the former.

In assessing the implications of the transcription of Roman names in Neo-Punic for understanding the Late Punic vowel system, we went beyond previous studies of the Neo-Punic vowel system by taking full account of zero-representation of vowel phonemes in Neo-Punic inscriptions. In this way we offered a picture of the system as presented through the transcription of Roman names in Neo-Punic that both builds upon previous studies 
and presents a more nuanced analysis (\$2.2.1). The differential treatment of Latin long and short vowels in Neo-Punic writing allowed us to show that Neo-Punic writers were sensitive to distinctions in Latin vowel length (\$2.2.2). These findings in turn permitted us to draw vowel triangles for Late Punic, and the means by which Neo-Punic represents vowels in Roman names (§2.2.3). We pointed out that these bear at least superficial similarity to the system in Classical Hebrew in some aspects, notably in the greater propensity for /u:, i:/ to be transcribed in contrast to their short variants $/ \mathrm{u}, \mathrm{i} /$.

In $\S 2.3$ we considered factors beyond vowel quality and quantity that may be said to affect whether or not a vowel is represented in Neo-Punic in the transcription of Roman names. We found that such vowel representation was sensitive both to the position of the Latin stress (§2.3.1) and absolute syllable position (\$2.3.2). This evidence is observed to contrast with the prevailing view on the position of the Punic stress (§2.3.3). We took this to suggest either that in the transcription of Roman names Neo-Punic writers ignored Punic stress patterns, or that the accepted picture of Late Punic stress patterns is in need of refinement.

In $\$ 2.4$ we assessed the implications for the Late Punic reading of the Latin vowel system. We concluded that transcription patterns are generally consistent both with the vowel system seen in Classical Latin, and with the distinctions of quality seen later in Sardinian Romance. This is to say that the developments seen in later varieties of Common Romance had not taken place 
in North Africa, at least by circa the second century CE. Furthermore, from the analysis of the marking versus non-marking of vowels in open syllables in $\$ 2.4 .5$, we were able to provide evidence that those composing the texts of the Neo-Punic inscriptions were more sensitive to the position of the Latin stress than to distinctions of vowel length, suggesting that open syllable lengthening may have begun in North Africa by the second century CE.

In $\S 3$ we demonstrated that the rate of confusion of $/ \mathrm{i}$, e:/ and /u, o:/ in Sardinia was extremely low, especially in stressed environments. In contrast to previous studies, all the available dated inscriptions from the island were analysed. Moreover, the literacy level of the writers was considered, which permitted us to avoid conclusions based on negative evidence. Furthermore, we took account of the dating of the inscriptions, which allowed us to better contextualise the phenomenon. This analysis permitted us to give evidence of the qualitative distinction between $/ \mathrm{i}$, e:/ and between / $\mathrm{u}, \mathrm{o} / \mathrm{/}$ on the island until at least the seventh century CE. This was further supported by the treatment of /i, e:/ in the transcription of Roman names into Neo-Punic in Sardinia up to the second century CE.

The plausibility of contact with North African speech communities being at least partly responsible for the outcome of the Sardinian vowel system was supported by archaeological, historical, and epigraphic sources, which all point to a strong presence of Latin and Neo-Punic bilingual speakers in both areas, a situation which persisted until well after the Roman conquest of the 
island. For these reasons, though further investigation is required, we believe that the common evolution of the two vowel systems in North African and Sardinian Latin should be at least partially ascribed to contact between Latin and Neo-Punic, reevaluating the importance of the common substratum of the two areas.

\subsection{REFERENCES}

Adams, James N. 2003. Bilingualism and the Latin language. Cambridge: Cambridge University Press.

- 2013. Social Variation and the Latin Language. Cambridge: Cambridge University Press.

Allen, William S. 1978. Vox Latina: A Guide to the Pronunciation of Classical Latin. Cambridge: Cambridge University Press.

Birley, Anthony R. 1996. 'Aurelius, Antoninus (1), Marcus'. In The Oxford Classical Dictionary, 3rd edition, edited by Simon Hornblower and Antony Spawforth, 221. Oxford: Oxford University Press.

Bruder, Carl Hermann. 1838. S. Aurelii Augustini De doctrina Christiana libri quatuor; et, Enchiridion ad Laurentium. Leipzig: Sumtibus et typis Caroli Tauchnitii.

De Felice, Irene, Margherita Donati, and Giovanna Marotta. 2015. 'CLaSSES: A New Digital Resource for Latin Epigraphy'. Italian Journal of Computational Linguistics 1 (1): 11930.

Fanciullo, Franco. 1992. Un capitolo della Romania submersa: Il latino africano. In Actes du XVIIIe Congrès International de 
Linguistique et de Philologie Romanes (Trier 1986), I, edited by Dieter Kremer, 162-187. Tübingen: Niemeyer.

Ferjaoui, Ahmed. 2007. 'L'onomastique dans les inscriptions néopuniques de l'Afrique à l'époque romaine'. Orientalia 76 (1): 33-46.

Forcellini, Egidio, Giuseppe Furlanetto, Francesco Corradini, and Giuseppe Perin. 1940. Lexicon Totius Latinitatis. Padua: Typis Seminarii.

Friedrich, Johannes, and Wolfgang Röllig. 1999. PhönizischPunische Grammatik, revised by Maria Giulia Amadasi Guzzo, in collaboration with Werner R. Meyer, 3rd edition. Analecta Orientalia 55. Rome: Pontifical Biblical Institute. Gaffiot, Félix. 1934. Dictionnaire illustré latin-français. Paris: Hachette.

Herman, Jószef. 1982. 'Un vieux dossier réouvert: les transformations du système latin des quantités vocaliques'. Bulletin de la Société de Linguistique de Paris 77: 285-302.

- 1985. 'La différenciation territoriale du latin et la formation des langues romanes'. In Mélanges de linguistique dédiés à la mémoire de Petar Skok (1881-1956), edited by Mirko Deanović, 207-16. Zagreb: Jugoslavenska Akademija Znanosti i Umjetnosti.

_. 1990. Du latin aux langues romanes: Études de linguistique historique. Tübingen: Niemeyer.

. 2000. Differenze territoriali nel latino parlato dell'Italia: Un contributo preliminare. In La preistoria dell'italiano. Atti della Tavola Rotonda di Linguistica Storica. Università Ca' Foscari 
di Venezia 11-13 giugno 1998, edited by Jószef Herman and Anna Marinetti, 123-35. Tübingen: Niemeyer.

Jongeling, Karel. 1984. 'Names in Neo-Punic Inscriptions'. PhD dissertation, University of Groningen.

- 2003. 'Use of Vowel Letters in Neo-Punic Texts from Guelma'. Dutch Studies on Near Easter Languages and Literatures 5 (1-2): 117-36.

- 2008. Handbook of Neo-Punic Inscriptions. Tübingen: Mohr Siebeck.

Jongeling, Karel, and Robert M. Kerr. 2005. Late Punic Epigraphy: An Introduction to the Study of Neo-Punic and Latino-Punic Inscriptions. Mohr Siebeck.

Keil, Heinrich. 1868. Artium scriptores minores: Cledonius, Pompeius, Iulianus excerpta ex commentariis in Donatum, Consentius, Phocas, Eutyches, Augustinus, Palaemon, Asper, De nomine et pronomine, De dubiis nominibus, Macrobii excerpta. Grammatici Latini 5. Leipzig: Teubner.

Kerr, Robert M. 2010. Latino-Punic Epigraphy: A Descriptive Study of the Inscriptions. Tübingen: Mohr Siebeck.

Lausberg, Heinrich, and Nicolò Pasero. 1971. Linguistica Romanza. Milan: Feltrinelli.

Leumann, Manu. 1977. Lateinische Grammatik. Lateinische Lautund Formenlehre, Munich: Beck.

Lewis, Charlton T., and Charles Short. 1879. A Latin Dictionary Founded on Andrews' Edition of Freund's Latin Dictionary. Oxford: Clarendon Press.

Lindsay, W. M. 1891. 'Latin accentuation'. The Classical Review 5 (8): 373-77. 
Loporcaro, Michele. 2011. 'Syllable, Segment and Prosody." In The Cambridge History of the Romance Languages, vol. 1: Structures, edited by Martin Maiden, John C. Smith, and Adam Ledgeway, 50-108. Cambridge: Cambridge University Press.

Lupinu, Giovanni. 2000. Latino epigrafico della Sardegna: Aspetti fonetici. Nuoro: Illisso.

Marotta, Giovanna. 2015. 'Talking stones: Phonology in Latin Inscriptions'. Studi e Saggi Linguistici 53 (2): 39-64.

- 2016. 'Sociolinguistica storica ed epigrafia latina: Il corpus CLaSSES I'. Linguarum Varietas 5: 145-60.

Mastino, Attilio. 1985. 'Le relazioni tra Africa e Sardegna in età romana: Inventario preliminare'. In L'Africa romana: Atti del 2. Convegno di studio, 14-16 dicembre 1984, edited by Attilio Mastino, 27-91. Sassari: Edizioni Gallizzi. 2002. 'La Sardegna romana'. In Storia della Sardegna. 1: Dalla preistoria all'età bizantina, edited by Manlio Brigaglia, Attilio Mastino, and Gian Giacomo Ortu, 52-92. Rome: Editori Laterza.

Nöldeke, Theodor. 1875. Mandäische Grammatik. Halle: Buchhandlung des Waisenhauses.

Paulis, Giulio. 1990. 'Sopravvivenze della lingua punica in Sardegna'. In L'Africa romana: Atti del 7. Convegno di studio, 15-17 dicembre 1989, Sassari (Italia), edited by Attilio Mastino, 599-639. Sassari: Edizioni Gallizzi.

Pisano, Simone. 2017. 'Lessico e formazione delle parole: Diacronia'. In Manuale di linguistica sarda, edited by Eduardo 
Blasco Ferrer, Peter Koch, and Daniela Marzo, 397-412. Berlin: De Gryuter.

Roppa, Andrea. 2015. 'Identifying Punic Sardinia: Local Communities and Cultural Identities in the Punic Mediterranean'. In Identities and Identification from Phoenician Settlement to Roman Rule, edited by Josephine C. Quinn and Nicholas C. Vella, 257-81. Cambridge: Cambridge University Press.

Rovai, Francesco. 2015. 'I rapporti tra i codici in due repertori complessi dell'antichità: Latino-gallico e latino-neopunico'. In Contatto interlinguistico tra presente e passato, edited by Carlo Consani, 197-216. Milan: LED Edizioni Universitarie. Rowland, Robert J. 1973. 'Onomastic Remarks on Roman Sardinia'. Names 21 (2): 82-102.

Rutherford, R. B. 1996. 'Aurelius, Marcus'. In The Oxford Classical Dictionary, 3rd edition, edited by Simon Hornblower and Antony Spawforth, 219. Oxford: Oxford University Press.

Sotgiu, Giovanna. 1961. Iscrizioni Latine della Sardegna I. Supplemento al Corpus Inscriptionum Latinarum 10 e all'Ephemeris Epigraphica 8. Padua: CEDAM.

1968. Iscrizioni Latine della Sardegna II: Instrumentum domesticum. I. Lucerne. Padua: CEDAM.

1988. 'L'epigrafia latina in Sardegna dopo il C.I.L. X e l'E.E. VIII'. In Aufstieg und Niedergang der römischen Welt (ANRW) 2: Principat 11.1, edited by Hildegard Temporini and Wolfgang Haase, 552-739. Berlin: De Gruyter.

Van Dommelen, Peter. 1998. 'Punic Persistence: Colonialism and Cultural Identities in Roman Sardinia'. In Cultural Identity 
in the Roman Empire, edited by Ray Laurence and Joanne Berry, 25-48. London: Routledge.

Wagner, Max L. 1997. La lingua sarda: Storia, Spirito e Forma. Edited by Giulio Paulis. Nuoro: Ilisso.

Wilson, Andrew. 2012. 'Neo-Punic and Latin Inscriptions in Roman North Africa: Function and Display'. In Multilingualism in the Greco-Roman Worlds, edited by Alex Mullen and Patrick James, 265-315. Cambridge: Cambridge University Press. 
